\title{
Prinsip Kerjasama Dan Kesantunan Pada Pembelajaran Bahasa Indonesia Dengan Pendekatan Saintifik
}

\author{
I Made Rai Arta ${ }^{1}$
}

\begin{abstract}
Abstrak
Tulisan ini memuat kajian prinsip kerjasama dan kesantunan yang berorientasi pada pembelajaran Bahasa Indonesia di kelas. Prinsip kerja sama itu, dibingkai dalam pendekatan saintifik yang dikemukakan oleh Geoffrey N. Leech, Brown and Levinson, dan Robin Lakoff. Kesimpulan dalam kajian ini menunjukkan siswa lebih aktif berinteraksi khususnya pada saat berdiskusi sehingga akan muncul aktivitas dengan prinsip kerjasama dan prinsip kesantunan. Selain itu, Dalam berinteraksi diperlukan komitmen untuk bekerjasama guna terciptanya efektivitas dalam mencapai tujuan pembelajaran.
\end{abstract}

Kata kunci: Prinsip kerjasama dan kesantunan, pendekatan saintifik.

\section{Pendahuluan}

Dalam interaksi yang baik akan terjadi komunikasi antara penutur dan mitratutur yang mengarah pada terjadinya kesalingmengertian sehingga komunikasi akan terjalin secara efektif. Sebagai alat komunikasi, bahasa merupakan saluran perumusan maksud, melahirkan perasaan, dan memungkinkan manusia menciptakan kerja sama. Leech (dalam Sudiara, 1999:2) menyatakan bahwa hakikat bahasa tidak akan membawa hasil seperti yang diharapkan tanpa disadari oleh pemahaman terhadap pragmatik, yakni bagaimana bahasa itu

${ }^{1}$ Guru Pendidikan Bahasa Bali di SMAN 1 Kuta Bali dan Mahasiswa Doctoral Undiksha 
digunakan dalam komunikasi. Kenyataan inilah yang menyebabkan pragmatik memiliki peranan yang cukup penting dalam kehidupan berbahasa. Dengan mempelajari dan menguasai bahasa, seluk beluk struktur sebuah bahasa, cara bahasa (ujaran) itu dipergunakan berdasarkan situasi yang dihadapi pada saat berkomunikasi. Penggunaan bahasa akan mmenjadi salah satu indikator karakteristik pemakainya. Pengguanaan bahasa yang sopan, santun, sistematis, teratur, jelas dan lugas cenderung menunjukkan pribadi penuturnya. Demikian sebaliknya penggunaan bahasa yang kasar seperti menghujat, memaki, mengejek, tidak sopan, cenderung memumjukkan pribadi yang tidak baik. Komunikasi bahasa seseorang memang merupakan cerminan psikologis.

\section{Komunikasi dan Prinsip Kesantunan}

Pada hakekatnya komumunikasi adalah interaksi menjalin hubungan sosial yang dilakukan dengan menggunakan ungkapan kesopanan dan ungkapan implisit. Strategi tersebut dilakukan oleh pembicara dan lawan bicara agar pesan tersampaikan dengan baik. Dengan demikian proses komunikasi terjalin secara sempurna.

Menurut Rahardi (2005: 35) kesantunan mengkaji penggunaan bahasa (language use) dalam suatu masyarakat bahasa tertentu. Masyarakat tutur yang dimaksud adalah masyarakat dengan aneka latar belakang situasi sosial dan budaya yang mewadahinya.Di pihak lain Fraser (melalui Rahardi, 2005: 38-40) menyebutkan bahwa sedikitnya terdapat empat pandangan yang dapat digunakan untuk mengkaji masalah kesantunan dalam bertutur.Pertama,kesantunanberkaitan dengan norma-norma sosial (thesocial-norm view). Dalam pandangan ini, kesantunan dalam bertutur ditentukan berdasarkan norma-norma sosial dan kultural yang ada dan berlaku di dalam masyarakat bahasa itu. Artinya kesantunan dalam bertutur ini disejajarkan dengan etika berbahasa (language etiquette).Kedua, kesantunan sebagai sebuah maksim percakapan(conversational maxim) dan sebagai sebuah upaya penyelamatan muka (facesaving).Pandangan kesantunan sebagai maksim percakapan menganggap prinsipkesantunan (politeness principle) hanyalah sebagai pelengkap prinsip kerja sama(cooperative principle). 
Menurut Chaer (2010: 10) ada tiga kaidah yang menmandai kesantunan . Ketiga kaidah itu adalah (1) formalitas (formality), (2) ketidaktegasan(hesistancy), dan (3) kesamaan atau kesekawanan (equality or camaraderie). Itu berarti dapat dikatakan bahwa sebuah tuturan disebut santun kalau tidak terdengar memaksa atau angkuh, tuturan itu memberi pilihan tindakan kepada lawan tutur, dan dapat menyenangkan lawan tutur.

Kesantunan berbahasa tercermin dalam tatacara berkomunikasi lewat tanda verbal atau tatacara berbahasa. Ketika berkomunikasi, kita tunduk pada norma norma sosio budaya, tidak hanya. Tata caraberbahasa harus sesuai dengan unsur-unsur budaya yang ada dalam masyarakat tempat hidup dan dipergunakannya suatu bahasa dalam berkomunikasi.

\section{Kerja sama dan Kesantuan dalam Pembelajaran}

Dalam berinteraksi sosial antar individu kehidupan sehari-hari,dengan menggunaan bahasa Indonesia dalam bentuk verbal, selalu terdapat prinsip kerja sama. Grice dalam Wijana (1996: 46) mengemukakan bahwa di dalam prinsip kerja sama itu, setiap penutur mematuhi empat maksim percakapan, yakni maksim kuantitas, maksim kualitas, maksim relevansi, dan maksim pelaksanaan.

\section{Maksim Kuantitas}

Maksim kuantitas menghendaki setiap peserta pertuturan memberikan kontribusi yang secukupnya atau sebanyak yang dibutuhkan oleh lawan bicaranya. Misalnya penutur yang berbicara secara wajar tentu akan memilih (1) dibandingkan dengan (2).

\section{Maksim Kualitas}

Maksim ini mewajibkan setiap peserta pecakapan mengatakan hal yang sebenarnya. Kontribusi peserta percakapan hendaknya didasarkan pada buktibukti yang memadai. Misalnya seorang harus mengatakan bahwa ibu kota Indonesia Jakarta bukan kota-kota yang lain, kecuali kalau benar-benar tidak tahu. Akan tetapi, bila terjadi hal yang sebaliknya, tentu ada alas an-alasan mengapa hal demikian bisa terjadi.

3.Maksim Relevansi 
Maksim relevansi mengharuskan setiap peserta percakapan memberikan kontribusi yang relevan dengan masalah pembicaraan.

\section{Maksim Pelaksanaan}

Maksim pelaksanaan mengharuskan setiap peserta percakapan berbicara secara langsung, tidak kabur, tidak taksa, dan tidak berlebih-lebihan serta runtut.

Kesantunan dalam bertutur dimaknai sebagai suatu kondisi menciptakan komunikasi yang efektif antara penutur dan mitra tutur.

Proses pembelajaran dikelas yang secara intruksional disusun tersencana,sistematis, terstruktur untukmencapaitujuan pembelajaran seharusnya berlandaskan atas norma kesantunan. Dalam wujud komunikasi, norma-norma tersebut tampak dari perilaku verbal dan nonverbal. Perilaku verbal dalam fungsi imperatif, terlihat pada cara penutur mengungkapkan perintah, keharusan, atau larangan melakukan sesuatu kepada mitra tutur, sedangkan perilaku nonverbal tampak dari sikap fisik mereka. Jadi kesantunan komunikasi tidak hanya terjadi dalam perilaku bermasyarakat, tetapi juga interaksi dalam proses belajar mengajar.

Dalam pembelajaran peserta didik siswa dilibatkan untuk mendapatkan pengetahuan yang cukup mermadai. Terjadi interaksi di kelas secara intensif. Beranjak dari hal inilah diharapkan kesantunan siswa terbangun melalui proses belajar mengajar. Dari proses interaksi inilah terjadi sebuah proses transfer ilmu pengetahuan.

Dilihat dari karakteristik pendekatan saintifik dalam pembelajaran, guru mempertimbangkan dan mengawasi,menghontrol penggunaan bahasa yang didasari oleh prinsip kesantunan dan prinsip kerja sama agar tercipta suatu iklim pembelajaran yang kondusif.Hal ini membawa konsekuensi siswa tidak tertekan secara psikologis. Dalam kenyataannya prinsip kesantunan yang dirumuskan oleh Leech sering dilanggar dan menyimpang pelaksanaannya dalam pembelajaran. Secara psikologis dapat dijelaskan bahwa penggunaan bahasa oleh siswa yang ang santun, dapat membuat proses pembelajaran yang sedang berlangsung menjadi tidak efektif. 
Leech (1993: 206-207), mengemukakan ada beberapa prinsip kesantunan berbahasa sebagai berikut.

\section{- Maksim Kebijaksanaan}

Gagasan pokok dalam maksim kebijaksanaan dalam kaitan prinsip kesantunan adalah penutur hendaknya berpegang pada prinsip untuk selalu mengurangi keuntungan dirinya sendiri dan memaksimalkan keuntungan pihak lain dalam kegiatan bertutur. Orang bertutur yang berpegang dan melaksanakan maksim kebijaksanaan akan dapat dikatakan sebagai orang santun.(Rahardi, 2005: 60). Tuturan yang diutarakan secara tidak langsung lazimnya lebih sopan dibandingkan dengan tuturan yang diutarakan secara langsung. Dalam maksim kebijaksanaan ini, Leech (1993: 206) menggunakan istilah maksim kearifan.

Rahardi .2005 : 60-61) mengemukakan contoh:

Tuan rumah : "Silakan makan saja dulu, nak!.Tadi kami semua sudah mendahului."

Tamu : "Wah, saya jadi tidak enak, Bu."

Informasi Indeksial:

Dituturkan oleh seorang Ibu kepada seorang anak muda yang sedang bertamu di rumah Ibu tersebut. Pada saat itu, ia harus berada di rumah Ibu tersebut sampai malam karena hujan sangat deras dan tidak segera reda. Dalam tuturan di atas, tampak dengan jelas bahwa apa yang dituturkan si tuan rumah sungguh memaksimalkan keuntungan bagi sang tamu. Lazimnya, tuturan semacam itu ditemukan dalam keluarga pada masyarakat tutur desa. Orang desa biasanya sangat menghargai tamu, baik tamu yang datangnya secara kebetulan maupun tamu yang sudah direncanakan terlebih dahulu kedatangannya.

\section{- Maksim Kedermawanan}

Rahardi (2005: 61) mengemukakan bahwa dalam maksim kedermawanan atau maksim kemurahan hati, penutur diharapkan dapat menghormati orang lain. Sikap hormat terhadap orang lain akan terjadi apabila orang dapat mengurangi keuntungan bagi dirinya sendiri dan memaksimalkan keuntungan bagi pihak lain. Chaer (2010: 60) menggunakan istilah maksim penerimaan 
untuk maksim kedermawanan Leech dalam Rahardi (2005: 62) memberikan contoh sebagai berikut.

Anak kos A : “ Mari saya cucikan baju kotormu! Pakaianku tidak banyak, kok, yang

kotor."

Anak kos B : "Tidak usah, Mbak. Nanti siang saya akan mencuci juga, kok!”

Informasi Indeksial:

Tuturan ini merupakan cuplikan pembicaraan antar anak kos pada sebuah rumah kos di kota Yogyakarta. Anak yang satu berhubungan demikian erat dengan anak yang satunya. Dari tuturan yang disampaikan si A di atas, dapat dilihat dengan jelas bahwa ia berusaha memaksimalkan keuntungan pihak lain dengan cara menambahkan beban bagi dirinya sendiri. Orang yang tidak suka membantu orang lain, apalagi tidak pernah bekerja bersama dengan orang lain, akan dapat dikatakan tidak sopan dan biasanya tidak akan mendapatkan banyak teman di dalam pergaulan keseharian hidupnya (Rahardi, 2005: 62).

- Maksim Penghargaan

Menurut Wijana (1996: 57) maksim penghargaan ini diutarakan dengan kalimat ekspresif dan kalimat asertif. Dalam maksim ini menuntut setiap penutur dituntut untuk memaksimalkan rasa hormat kepada orang lain, dan meminimalkan rasa tidak hormat kepada orang lain. Selanjutnya Rahardi (2005: 63) mengemukakan dalam maksim penghargaan dijelaskan bahwa orang akan dapat dianggap santun apabila dalam bertutur selalu berusaha memberikan penghargaan kepada pihak lain. Dengan maksim ini, diharapkan agar para peserta pertuturan tidak saling mengejek, saling mencaci, atau saling merendahkan pihak lain. contoh:

Dosen A : “ Pak, aku tadi sudah memulai kuliah perdana untuk kelas Bussines

\section{English."}

Dosen B : "Oya, tadi aku mendengar Bahasa Inggrismu jelas sekali dari sini." 


\section{Informasi Indeksial:}

Dituturkan oleh seorang dosen kepada temannya yang juga seorang dosen dalam ruang kerja dosen pada sebuah perguruan tinggi (Rahardi, 2005: 63). Pemberitahuan yang disampaikan dosen A terhadap rekannya dosen B pada contoh di atas, ditanggapi dengan sangat baik bahkan disertai pujian atau penghargaan oleh dosen A. Dengan demikian, dapat dikatakan bahwa di dalam pertuturan itu, dosen B berperilaku santun (Rahardi, 2005: 63).

- Maksim Kesederhanaan

Rahardi (2005: 63) mengatakan bahwa di dalam maksim kesederhanaan atau maksim kerendahan hati, peserta tutur diharapkan dapat bersikap rendah hati dengan cara mengurangi pujian terhadap dirinya sendiri. Wijana (1996: 58) mengatakan maksim kerendahan hati ini diungkapkan dengan kalimat ekspresif dan asertif. Bila maksim kemurahan atau penghargaan berpusat pada orang lain.Maksim ini menuntut setiap peserta pertuturan untuk memaksimalkan ketidakhormatan pada diri sendiri, dan meminimalkan rasa hormat pada diri sendiri.

contoh:

Sekretaris A : "Dik, nanti rapatnya dibuka dengan doa dulu, ya!"

Sekretaris B : "Ya, Mbak. Tapi saya jelek, lho."

Informasi Indeksial:

Dituturkan oleh seorang sekretaris kepada sekretaris lain yang masih junior pada saat mereka bersama-sama bekerja di ruang kerja mereka (Rahardi,2005: 64). Dari tuturan sekretaris B di atas, dapat terlihat bahwa ia bersikap rendah hati dan mengurangi pujian untuk dirinya sendiri. Dengan demikian, tuturan tersebut terasa santun.

\section{- Maksim Permufakatan}

Menurut Rahardi (2005: 64) dalam maksim ini, ditekankan agar para peserta tutur dapat saling membina kecocokan atau kemufakatan di dalam kegiatan bertutur. Apabila terdapat kemufakatan atau kecocokan antara diri penutur dan mitra tutur dalam kegiatan bertutur, masing-masing dari mereka akan dapat dikatakan bersikap santun. Wijana (1996: 59) menggunakan istilah 
maksim kecocokan dalam maksim permufakatan ini. Maksim kecocokan ini diungkapkan dengan kalimat ekspresif dan asertif. Maksim kecocokan menggariskan setiap penutur dan lawan tutur untuk memaksimalkan kecocokan di antara mereka, dan meminimalkan ketidakcocokan di antara mereka.

contoh:

(5) Noni : "Nanti malam kita makan bersama ya, Yun!"

Yuyun : "Boleh. Saya tunggu di Bambu Resto."

Informasi Indeksial:

Dituturkan oleh seorang mahasiswa kepada temannya yang juga mahasiswa pada saat mereka sedang berada di sebuah ruangan kelas (Rahardi, 2005: 65). Tuturan di atas terasa santun, karena Yuyun mampu membina kecocokan dengan Noni. Dengan memaksimalkan kecocokan di antara mereka tuturan akan menjadi santun.

- Maksim Kesimpatian

Leech (1993: 207) mengatakan di dalam maksim ini diharapkan agar para peserta tutur dapat memaksimalkan sikap simpati antara pihak yang satu dengan pihak lainnya. Sikap antipati terhadap salah seorang peserta tutur akan dianggap sebagai tindakan tidak santun. Orang yang bersikap antipati terhadap orang lain, apalagi sampai bersikap sinis terhadap pihak lain, akan dianggap sebagai orang yang tidak tahu sopan santun di dalam masyarakat (Rahardi, 2005: 65). Menurut Wijana (1996: 60), jika lawan tutur mendapatkan kesuksesan atau kebahagiaan, penutur wajib memberikan ucapan selamat. Bila lawan tutur mendapatkan kesusahan, atau musibah, penutur layak turut berduka, atau mengutarakan ucapan bela sungkawa sebagai tanda kesimpatian. contoh:

(6) Ani : "Tut, nenekku meninggal."

Tuti : "Innalillahiwainailaihi rojiun. Ikut berduka cita."

Informasi Indeksial:

Dituturkan oleh seorang karyawan kepada karyawan lain yang sudah berhubungan erat pada saat mereka berada di ruang kerja mereka (Rahardi, 2005: 66). Dari tuturan di atas, terlihat Tuti menunjukkan rasa simpatinya 
kepada Ani. Orang yang mampu memaksimalkan rasa simpatinya kepada orang lain akan dianggap orang yang santun.

\section{Indikator Pencapaian Kesantunan dalam Pembelajaran}

Kesantunan yang biasa disebut "tatakrama", paling tidak ada tiga indikator pencapaian kesantunan berbahasa dalam pembelajaran dengan pendekatan saintifik. Ketiga indikator yang dirumuskan dalam wujud skala itu adalah . (1) skala kesantunan menurut Geoffrey N. Leech, (2) skala kesantunan menurut Brown and Levinson, dan (3) skala kesantunan menurut Robin lakoff.

Leech selanjutnya menjabarkan skala kesantunan sebagai berikut.

a. Cost-benefit scale atau skala kerugian-keuntungan. Skala ini mengacu pada tingkat besar kecilnya kerugian dan keuntungan yang diakibatkan oleh tindak tutur di dalam proses pertuturan tersebut. Dalam hal ini, semakin merugikan bagi diri si penuturnya sendiri, maka cenderung akan semakin dianggap santunlah tuturan tersebut. Sebaliknya, semakin tuturan itu menguntungkan diri penuturnya, maka semakin tidak sopan tuturan tersebut..

b. Optionality scale atau skala pilihan. Skala ini mengacu pada banyak atau sedikitnya alternatif pilihan (options) yang disampaikan penutur kepada mitra tutur dalam interaksi tuturan. Misalnya saja pemakaian bentuk imperatif di dalam bahasa Indonesia, bentuk imperatif tersebut akan dikatakan memiliki kadar kesantunan yang tinggi apabila menyajikan banyak kemungkinan pilihan bagi si penerima perintahnya.

c. Indirectness scale atau skala ketidaklangsungan. Skala kesantunan ini mengacu pada tingkat langsung atau tidak langsungnya maksud sebuah tuturan. Semakin singkat dan dan langsung suatu tuturan, akan dianggap semakin tidak santunlah tuturan tersebut. Sebaliknya, semakin tidak langsung maksud sebuah tuturan, akan semakin santunlah tuturan tersebut.

d. Authority scale atau skala keotoritasan atau skala kekuasaan. Skala ini mengacu pada status sosial antara si penutur dan mitra tutur. Semakin jauh status sosial antara penutur dan mitra tutur akan semakin santunlah tuturan 
tersebut.

5) Social scale atau skala jarak sosial. Skala iini mengacu pada tingkat hubungan sosial antara si penutur dan mitra tutur yang terlibat di dalam pertuturan. Ada kecenderungan bahwa semakin dekat jarak peringkat sosial di antara keduanya, akan menjadi kurang santunlah tuturan itu.

Dalam model Brown dan Levinson (1987) terdapat tiga skala tingkat kesantunan berbahasa.

a Skala peringkat jarak sosial antara penutur dan mitra tutur. (social between speaker and hearer). Skala ini sangatditentukan oleh karakteristik perbedaan dalam soal jenis kelamin, dan sosiokultural seseorang. Semakin tua umur seseorang, tingkat kesantunan dalam tuturnya akan semakin tinggi.. Dari sosiokultural adalah orang yang memiliki jabatan tertentu cenderung memiliki peringkat kesantunan lebih tinggi.

b Skala status sosial antara penutur dan mitra tutur (the speaker and hearer relative power) atau s disebut dengan tingkat kekuatan atau kekuasaan (power rating). Misalnya di ruang kelas seorang guru dianggap memiliki peringkat kekuatan atau kekuasaan yang lebih tinggi dibandingkan dengan murid..

c Skala peringkat tindak tutur atau tindak ujar atau serig disebut rank rating. Skala berbahasa ini didasarkan atas kedudukan relatif tindak tutur yang satu dengan tindak tutur yang lain.

BerikutnyaTeori Lakoff (1973) dapat disebut sebagai induk teori kesantunan modern karena teori ini merupakan salah satu teori pertama yang digunakan untuk menguji kesantunan dari perspektif pragmatik. Robin Lakoff menyatakan terdapat tiga ketentuan skala kesantunan di dalam kegiatan bertutur di dalam masyarakat yaitu : 1) Skala formalitas (formality scale), agar para peserta tutur dapat merasa benar-benar nyaman di dalam proses bertutur, . 2) Skala ketidaktegasan atau skala keraguan (besitancy scale) atau disebut juga skala pilihan (optionality scale), menunjukkan bahwa agar si penutur dan mitra tutur tidak merasa ragu dan merasa tidak ada ketegasan dalam bertutur, 3) Peringkat kesekawanan atau kesamaan, m penutur enganggap pihak mitra tutursebagai sahabat sehingga muncul rasa kesekawanan, rasa solider, dan rasa 
kesejajaran sebagai salah satu prasyarat hadirnya kesopanan dan kesantunan akan tercapai dengan benar-benar baik.

\section{Penerapan Prinsip Kerja Sama dan Prinsip Kesantunan dengan Pendekatan Saintifik}

Dalam pembelajaran dalam kelas dengan pendekatan saintifik, siswa dituntut untuk aktif berinteraksi khususnya pada saat berdiskusi sehingga akan muncul aktivitas dengan prinsip kerja sama dan tentunya muncul prinsip prinsip kesantunan. Secara operasional, prinsip-prinsip itu dengan pendekatan saintifis akan diwarnai dengan beberapa langkah, yaitu :

1. Mengamati. Dalam kegiatan mengamati, guru membuka secara luas dan bervariasi kesempatan peserta didik untuk melakukan pengamatan melalui kegiatan: melihat, menyimak, mendengar, dan membaca. Guru memfasilitasi peserta didik untuk melakukan pengamatan, melatih mereka untuk memperhatikan (melihat, membaca, mendengar) hal yang penting dari suatu benda atau objek.

2. Menanya Dalam kegiatan mengamati, guru membuka kesempatan secara luas kepada peserta didik untuk bertanya mengenai apa yang sudah dilihat, disimak, dibaca atau dilihat. Guru perlu membimbing peserta didik untuk dapat mengajukan pertanyaan: pertanyaan tentang hasil pengamatan objek yang konkret sampai kepada yang abstrak berkenaan dengan fakta, konsep, prosedur, atau pun hal lain yang lebih abstrak. Pertanyaan yang bersifat faktual sampai kepada pertanyaan yang bersifat hipotetik.

Dari situasi di mana peserta didik dilatih menggunakan pertanyaan dari guru, masih memerlukan bantuan guru untuk mengajukan pertanyaan sampai ke tingkat di mana peserta didik mampu mengajukan pertanyaan secara mandiri.

Dari kegiatan kedua dihasilkan sejumlah pertanyaan. Melalui kegiatan bertanya dikembangkan rasa ingin tahu peserta didik. Semakin terlatih dalam bertanya maka rasa ingin tahu semakin dapat dikembangkan. Pertanyaan tersebut menjadi dasar untuk mencari informasi yang lebih lanjut dan beragam 
dari sumber yang ditentukan guru sampai yang ditentukan peserta didik, dari sumber yang tunggal sampai sumber yang beragam.

3.Mengumpulkan informasi/eksperimen

Tindak lanjut dari bertanya adalah menggali dan mengumpulkan informasi dari berbagai sumber melalui berbagai cara. Untuk itu peserta didik dapat membaca buku yang lebih banyak, memperhatikan fenomena atau objek yang lebih teliti, atau bahkan melakukan eksperimen. Dari kegiatan tersebut terkumpul sejumlah informasi. Anak perlu dibiasakan untuk menghubung-hubungkan antara informasi satu dengan yang lain, untuk mengambil kesimpulan. Anak perlu dihadapkan dengan sekumpulan fakta yang memiliki unsur kesamaan agar ditemukan polanya.

4. Mengasosiasikan/mengolah informasi Informasi tersebut menjadi dasar bagi kegiatan berikutnya yaitu memeroses informasi untuk menemukan keterkaitan satu informasi dengan informasi lainnya, menemukan pola dari keterkaitan informasi dan bahkan mengambil berbagai kesimpulan dari pola yang ditemukan.Kegiatan mengolah informasi yang sudah dikumpulkan baik terbatas dari hasil kegiatan mengumpulkan/eksperimen mau pun hasil dari kegiatan mengamati dan kegiatan mengumpulkan informasi.

Pengolahan informasi yang dikumpulkan dari yang bersifat menambah keluasan dan kedalaman sampai kepada pengolahan informasi yang bersifat mencari solusi dari berbagai sumber yang memiliki pendapat yang berbeda sampai kepada yang bertentangan.

\section{Mengkomunikasikan}

Kegiatan berikutnya adalah menuliskan atau menceritakan apa yang ditemukan dalam kegiatan mencari informasi, mengasosiasikan dan menemukan pola. Hasil tersebut didiskusikan di kelas dan dinilai oleh guru sebagai hasil belajar peserta didik atau kelompok peserta didik tersebut. perlu Peserta didik dibiasakan untuk mengemukakan dan mengkomunikasikan ide, pengalaman, dan hasil belajarnya kepada orang lain. 
I Made Rai Artal Prinsip Kerjasama Dan Kesantunan Pada Pembelajaran Bahasa Indonesia Dengan Pendekatan Saintifik

\section{Penutup}

Dalam pembelajaran dalam kelas dengan pendekatan saintifik, siswa dituntut untuk aktif berinteraksi khususnya pada saat berdiskusi sehingga akan muncul aktivitas dengan prinsip kerja sama dan tentunya muncul prinsip prinsip kesantunan. Dalam berinteraksi diperlukan komitmen untuk bekerjasama guna terciptanya efektivitas dalam mencapai tujuan pembelajaran. Tentu kerja sama itu dilandasi dengan pemakaian tuturan dengan prinsip kesantunan dengan skala yang dikemukakan oleh Geoffrey N. Leech, Brown and Levinson, dan Robin Lakoff.

\section{DAFTAR PUSTAKA}

Chaer, Abdul.2010. Kesantunan Bahasa. Jakarta : Rhineka Cipta

Kemendiknas .2013. Pembelajaran Tematik Terpadu dengan Pendekatan Saintifiks.

Leech, Geoffrey.2010. Prinsip-Prinsip Pragmatik. Terjemahan M.D.D. Oka. Jakarta : Universitas Indonesia.

Rahardi, Joni dkk. 2005. “ Sopan-Santun Bahasa Jawa diLingkunganKeluarga: Sebuah Kajian Sosiodialektologi” .Jurnal Ilmiah.Jogyakarta.

Sudiara.1999. Pragmatik Kesantunan Imperatif Bahasa Indonesia. Yogyakarta : PP Gelora Aksara Pratama.

Susilowati, Eka.2011. Penerapan Prinsip Kerja sama dan Kesantunan dalam Percakapan Bahasa Jawa di Wisma Hayam Wuruk 56 Semarang. Tesis Surakarta : Universitas Surakarta.

Tarigan, Henry Guntur. 2009. Pengajaran Pragmatik: Bandung Angkasa.

Wijana, I Dewa Putu. 2016. Dasar-Dasar Pragmatik. Jogyakarta : Andy. 